\author{
Lidia GAWLIK ${ }^{1}$ \\ Dominik KRYZIA ${ }^{2}$ \\ Monika PEPLOWSKA ${ }^{3}$
}

\title{
THE IMPACT OF COAL MINING REDUCTION ON THE ENERGY MIX OF POLAND
}

\begin{abstract}
The article is aimed at assessing the impact of reducing coal mining on the energy mix of Poland. Taking into account the current economic situation in the mining industry and its key role in the raw material economy of the country, the authors have attempted to assess the impact of the reduction the size or abandoning the production of hard coal mining in Poland on the situation in domestic energy sector and to present some of the resulting consequences. It is important that the share of coal in the national energy mix decreases each year, mainly in favor of natural gas and renewable energy sources. The wind power share in energy systems is increasing each year. This situation takes place both worldwide and in Poland. This development is a result of introducing requirements dictated by the conduct of climate policy. The energy solutions, which have a positive impact on the environment and climate change are mainly supported. However, it should be noted that in 2015 more than $50 \%$ of electricity was generated from burning hard coal in power generation plants. The vast majority of Polish power plants are hard coal fired power plants. A much smaller number are power plants powered by another type of fuel, including power plants powered by renewable energy sources. Currently, new capacities based on this fuel, i.e.: Kozienice, Jaworzno, and Opole power plants, are being built. The abovementioned conditions and the results of detailed analysis indicate that hard coal will continue to be used in Poland for many years.
\end{abstract}

Keywords: coal mining, electricity production, energy mix, forecasts.

\section{INTRODUCTION}

Coal is the primary fuel used for electricity generation in Poland. Meanwhile, hard coal mining in Poland is currently facing a number of serious challenges, and its long-term role is dependent on many factors, both at national and international level.

Hard coal mining in Poland has reported a 2 billion PLN loss for 2015. This was the third consecutive difficult year for the industry. The aforementioned loss in 2014 amounted to over 2 billion PLN, while in 2013 it was 300 million PLN. Coal companies are lacking financial liquidity and are struggling with payment of salaries, while there are no investment

\footnotetext{
${ }^{1}$ Dr hab. inż. Lidia Gawlik, Mineral and Energy Economy Research Institute, Polish Academy of Sciences, prof. IGSMiE PAN, 31-261 Krakow, Wybickiego 7; e-mail: lidia.gawlik@min-pan. krakow.pl.

2 Dr inż. Dominik Kryzia, Mineral and Energy Economy Research Institute, Polish Academy of Sciences, 31-261 Krakow, Wybickiego 7; e-mail: kryzia@min-pan.krakow.pl.

${ }^{3}$ Mgr inż. Monika Pepłowska, Mineral and Energy Economy Research Institute, Polish Academy of Sciences, 31-261 Krakow, Wybickiego 7; e-mail: monika@min-pan.krakow.pl.
} 
funds. Such a difficult situation of the mining industry requires undertaking restructuring measures, including actions aimed at protecting miners' jobs. The establishment of the Polish Mining Group (PGG) can serve as an example. The acquisition of Coal Company by PGG is an attempt to save the largest coal company in Europe. However, it is not the end of troubles and uncertainties facing the mining entities. Achieving the long-term economic efficiency of coal mining industry will be a lengthy process, requiring a comprehensive analysis of long-term action plans. It is obvious that coal entities should extract as much coal as can be consumed at prices higher than the production costs.

The challenge facing the Polish mining industry is the EU climate policy. High carbon dioxide emissions during coal combustion are not favorable for its use in the energy sector, while the intensification of the EU actions aimed at increasing efforts on climate protection ${ }^{4}$ will undoubtedly have an impact on both the position of coal as a fuel for power generation and the whole economy.

\section{THE SITUATION OF HARD COAL MINING SECTOR}

Mining remains the main source of primary fuels to the national economy. The use of domestic resources ensures Poland one of the highest levels of energy security among the European countries ${ }^{5}$.

For many years there has been a reduction in demand for Polish coal. In 2007, the mining industry has sold 86.9 million $\mathrm{Mg}$, while in 2015 it has sold 13.3 million Mg less. In 2015, the mining industry has sold 73.6 million $\mathrm{Mg}$ of coal, of which 64.6 million $\mathrm{Mg}$ in the domestic market and 9 million $\mathrm{Mg}$ in the international market. The main customer is the commercial and industrial power generation, consuming 36.6 million $\mathrm{Mg}$, which constitutes almost half $(49.7 \%)$ of the total coal sales. Other domestic hard coal recipients are:

- Coking plants - 10.7 million $\mathrm{Mg}$,

- CHP plants (both commercial and industrial) - 4.3 million $\mathrm{Mg}$,

- Other industrial customers - 0.4 million $\mathrm{Mg}$,

- Other domestic customers - 12.5 million $\mathrm{Mg}$.

The sales of Polish coal for commercial and industrial power generation over the past few years are shown in Fig. 1. Despite fluctuations in sales between individual years, a clear downward trend can be observed.

The decline in coal prices on world markets, prolonged since 2011, is commonly believed as the main reason for the abovementioned difficult situation. As a result, there has been a decrease in coal prices in both domestic and international markets, while the production costs have increased. The high availability of coal at low prices in the world markets hinders the export of Polish coal, while making imported coal a significant competitor in the domestic market. The use of cheap, imported coal has become a permanent phenomenon in Poland in recent years; the average import of this raw material in the years 2007-2015 amounted to 10.6 million tons per year, which represents more than $13 \%$ of coal production in this period.

\footnotetext{
${ }^{4}$ Communication from the Commission to the European Parliament, the Council, the Economic and Social Committee and the Committee of the Regions. Energy Roadmap 2050, COM(2011) 885/2 final. European Commission (EC), 2011.

5 European Union, 2015. Energy, transport and environment indicators. Luxemburg Publication Office of the European Union.
} 


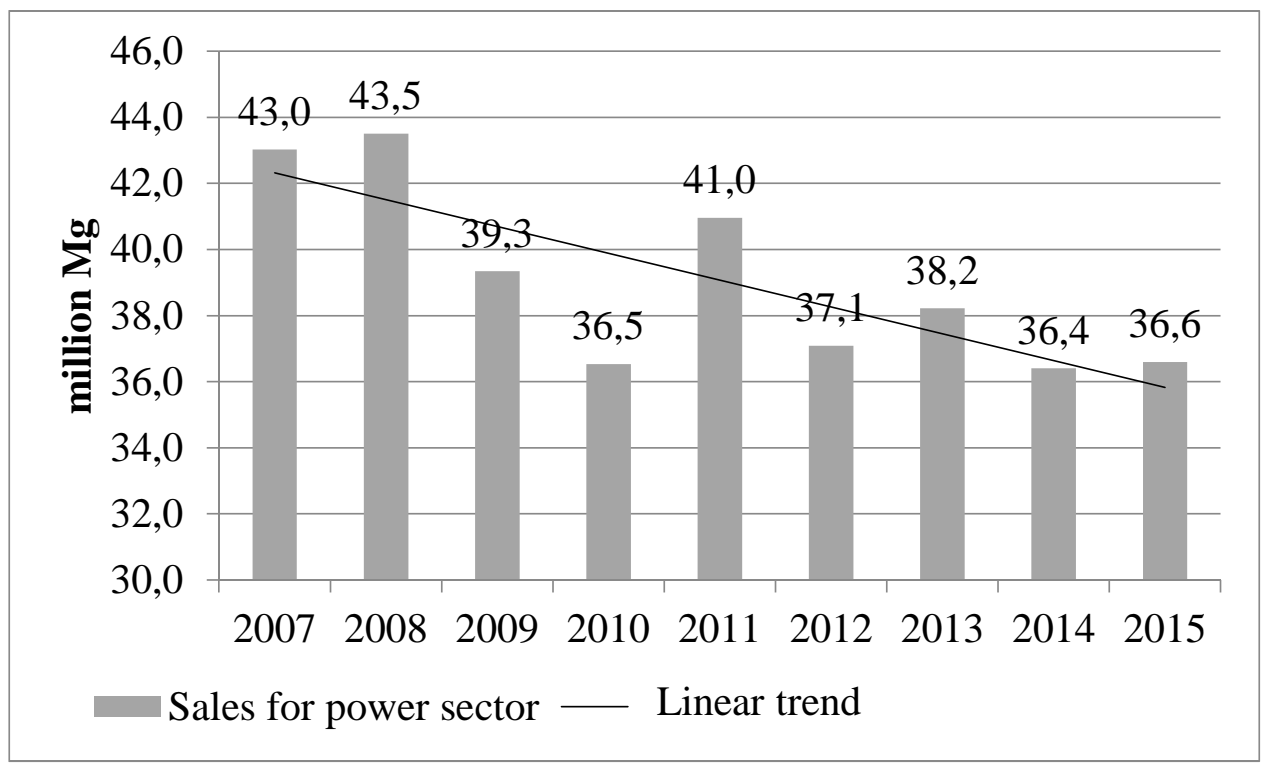

Fig. 1. The sales of coal for commercial and industrial power generation in the years 2007-2015

Source: Agencja Rozwoju Przemysłu S.A. Oddział w Katowicach, data processed on the basis of the results of the survey of public statistics by the Minister of Economy „Coal mining“, executed by ARP SA O / Katowice 2015.

Adjusting the volume of coal mining to the possibility of effective sales is a very important and urgent task for today, but these actions must take into account the long-term forecast of demand for this raw material.

It should be emphasized that the documented balance resources of coal amount to more than 52 billion $\mathrm{Mg}$, but the exploitable resources, included in mine development plans, are only 1.813 billion $\mathrm{Mg}$ - taking into account the resources in deposits for which concessions for mining activities have already been granted to mining companies - or 3.39 billion $\mathrm{Mg}$ for all deposits ${ }^{6}$. In order to estimate exploitable resources, a mine development plan is required $^{7}$. These are the extractable resources estimated on the basis of mining development plans taking into account the rate of exploitation of a deposit. The sufficiency of exploitable resources calculated as the ratio of the size of these resources to the production volume is about 25 years, while restructuring plans will lead to inevitable loss of part of the resources.

The specific nature of the mining industry requires constant expenses for opening of new deposits and their parts in order to make exploitation process stable. For example, the lack of investments for deepening coal mine shafts in the past has contributed to the fact that over $30 \%$ of the current extraction is carried out in deposits located below the deepest

\footnotetext{
${ }^{6}$ J. Kicki, E.J. Sobczyk, J. Jarosz, K. Stachurski, Gospodarka zasobami złóż węgla kamiennego w Polsce w latach 1990-2015, Zeszyty Naukowe Instytutu Gospodarki Surowcami Mineralnymi i Energią PAN, 2016, No. 92, p. 37-56.

${ }^{7}$ Rozporządzenie Ministra Środowiska z dnia 24 kwietnia 2012 r. w sprawie szczegółowych wymagań dotyczących projektów zagospodarowania złóż (Dz.U. z 2012 r., poz. 511).
} 
edge of shafts, which increases the extraction costs and is unfavorable for security conditions in mines. However, in order to incur such expenditures, mining companies must have a clear perspective of their operation.

The demand for hard coal for power generation in the future is one of the most important factors determining the depth of the reforms already needed in the mining industry.

\section{THE SITUATION OF POWER GENERATION INDUSTRY}

The share of solid fuels in the production of electricity and heat is very high (Fig. 1).

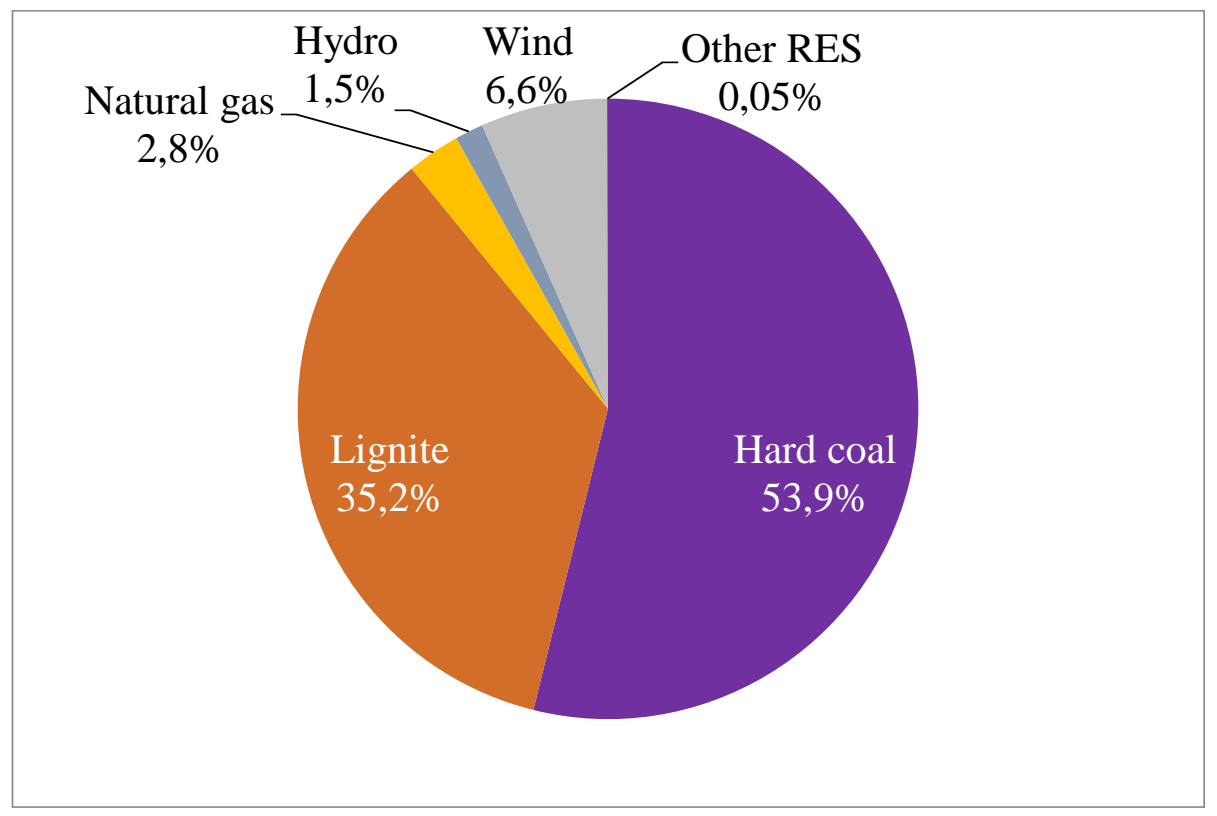

Fig. 2. Structure of electricity generation in the commercial power industry in 2015 .

Source: Polskie Sieci Elektroenergetyczne SA. [online] http://www.pse.pl/index.php?modul= $8 \& \mathrm{y}=2015 \& \mathrm{~m}=12 \&$ id_rap=212 available 1.05.2016.

In the last few years, there has been a decrease in the share of hard coal in the structure of electricity production from $61.6 \%$ in 2007 to $53.9 \%$ in 2015 . The comparable size of electricity generation was accompanied by a decrease in electricity production in coal-fired power plants in favor of electricity generation from lignite (which is a cheaper fuel) and the dynamic development of wind energy (Table 1).

Coal power units have been modernized in the past, which partially improved their efficiency. They are also fitted with flue gas cleaning installations, reducing their negative impact on the environment. However, the manufacturing base of the power sector is obsolete and often characterized by its low efficiency. Therefore, significant part of power units will have to be phased out in the coming years, not only because of their condition, but also because of the growing requirements of the EU on emission limits. It is estimated that by 
2050 about $18 \mathrm{GW}$ of existing solid fuel-fired units will have to be decommissioned ${ }^{8,9}$. The future role of coal in power generation will depend on the direction of development of the Polish power industry, the chosen priorities, and selected fuel types.

Table 1. Comparison of electricity production in the years 2007 and 2015 in the power industry

\begin{tabular}{|l|r|r|r|}
\hline Item & \multicolumn{1}{|c|}{2007} & \multicolumn{1}{|c|}{2015} & \multicolumn{1}{|c|}{ Difference } \\
\hline Hard coal-fired power plants & 93133 & 81883 & -11250 \\
\hline Lignite-fired power plants & 51142 & 53564 & 2422 \\
\hline Gas-fired power plants & 3908 & 4193 & 285 \\
\hline Hydroelectric power plants & 2682 & 2261 & -421 \\
\hline Wind power plants & 436 & 10041 & 9605 \\
\hline Other renewable sources & 11 & 73 & 62 \\
\hline Total electricity production & 151312 & 152015 & 703 \\
\hline
\end{tabular}

Source: Polskie Sieci Elektroenergetyczne SA. [online]...

The Polish government efforts on the development of new energy policy of Poland have been ongoing for several years. The delay results from the importance of the issue, because defining the priorities of development requires taking into account a number of conditions deriving from internal and external factors, while the government change in autumn 2015 has also contributed to this issue. It is expected that this document will clarify the role of hard coal mining while taking into account its crucial importance for the security of fuel supplies to the heat and power sector and the social importance of hard coal mining, securing jobs for more than a hundred thousand of miners. The directions of energy development should take into account the elements associated with the EU Energy and Climate Package, focusing on the reduction of greenhouse gas emissions from the energy sector. It is also important to ensure the availability of electricity at reasonable prices for both the society and the energy sector in order to enhance the competitiveness of Poland in the international market.

Special attention should be paid to the issue of domestic fuel and energy balance, as any negligence in this sensitive area at the stage of defining the directions of development of the Polish energy sector can lead to irreversible and negative effects in the long run ${ }^{10}$.

The government, already at the stage of preparing the strategic document on energy policy, has declared that coal will remain the main source of energy in the country. This view is supported by - in addition to the abundance of coal resources, well-developed mining industry and coal-fired capacities - research and development studies on clean coal technologies, aimed at improving the efficiency of extraction, processing, and utilization of coal in order to increase the acceptability of these processes from the environmental point

\footnotetext{
${ }^{8}$ L. Gawlik, A. Szurlej, A. Wyrwa, The impact of the long-term EU target for renewables on the structure of electricity production in Poland, "Energy" 2015, No. 92 (Polish Energy Mix) 2015, p. 172-178.

9 W.M. Budzanowski, Target for national carbon intensity of energy by 2050: A case study of Poland's energy system, "Energy" 2012, Vol. 46, p. 575-581.

${ }^{10}$ L. Gawlik, M. Kaliski, J. Kamiński, A.P. Sikora, A. Szurlej, Hard coal in the fuel-mix of Poland: the long-term perspective, “Arch. Min. Sci.” 2016, Vol. 61, No 2, p. 339-354.
} 
of view ${ }^{11}$. The development of modern coal-fired units, characterized by high efficiency and low emissions, is crucial for the use of coal in power generation.

Boilers and turbines with supercritical parameters, i.e. temperature of $600 / 620^{\circ} \mathrm{C}$ and pressure of 25-30 MPa, are currently available in the market. Supercritical units in Poland operate in the Pątnów (460 MW), Łagisza (460 MW) and Bełchatów Power plants (858 MW). The units currently being built in Kozienice power plant (1,075 MW) can also be classified in this category.

New supercritical coal-fired boilers are being constructed in the Opole (2x900 MW), Jaworzno (910 MW), and Turów power plants (496 MW, lignite-fired boiler). Therefore, there is a belief that it is possible to continue effective electricity generation from coal. Moreover, newly built power plants will become a part of the production base and will be operated for many years, thus determining the use of coal in power generation.

In recent years, as part of a strategic project ,Advanced Technologies for Energy Generation" numerous research tasks have been carried out, while three of them were directly related to coal ${ }^{12}$ :

- The development of technology for highly efficient "zero-emission" coal-fired units integrated with carbon capture and storage from flue gases,

- The development of oxide combustion technology for pulverized and fluidized bed boilers with integrated carbon capture and storage technology,

- The development of coal gasification technology for highly efficient production of fuels and electricity

The efforts on the use of carbon capture and storage technology on an industrial scale constitute an important element of progress in reducing greenhouse gas emissions in coal combustion processes.

The energy policy of Poland, which will determine the structure of production in the energy sector, should be supported by test results, which will ensure a balance between the three elements of sustainable development ${ }^{13}$. The widely accepted doctrine of sustainable development, also in the case of Polish energy policy, is based on three elements:

- Ensuring energy security - and therefore the stability of energy supplies,

- Ensuring the availability of electricity at affordable prices for both the society and the energy sector,

- Reducing environmental impact of the electricity production.

Therefore, the main objective of energy policy is the optimal development of stable, inexpensive, and environmentally friendly energy systems. Poland was ranked 45 among 130 countries in the assessment of the sustainability of national energy systems conducted by the World Energy Council in 2015 (BBD rank) ${ }^{14}$. According to the assessment, Poland has a good level of energy security (B) due to the use of domestic resources of raw materials,

${ }^{11}$ K. Kubica, A. Szlęk, R. Wilk, Czyste technologie węglowe - badania, rozwój i upowszechnianie wyników, Gliwice 2007.

12 Narodowe Centrum Badań i Rozwoju [online], http://www.ncbr.gov.pl/programy-strategiczne/zaawansowane-technologie-pozyskiwania-energii/ available 20.05.2016.

132015 Trillema Index: benchmarking the sustainability of national energy systems. World Energy Council, London 2015, 151 p. [online] http://www.worldenergy.org/publications/2015/2015energy-trilemma-index-benchmarking-the-sustainability-of-national-energy-systems-2/ available 25.05.2016.

${ }^{14}$ Ibidem. 
while the energy is relatively inexpensive - and therefore available for the society (B), but when it comes to environmental aspects, Poland ranks low (D). This element should be improved in the future. However, reducing the impact of energy on the environment should not negatively affect (at least not significantly) the national energy security and economic competitiveness of the country.

\section{DIRECTIONS OF DEVELOPMENT OF THE POLISH POWER SYSTEM - THE RESULTS OF SCENARIOS ANALYZES}

Investments in new generating capacities of the power sector are usually preceded by detailed studies, including project valuation taking into account numerous factors and the risk assessment ${ }^{15}$. Investment decisions in the power sector require determining and minimizing the costs of energy production for different technologies. Sophisticated methods, techniques and tools help to succeed despite the uncertainty of the future performance ${ }^{16}$. This uncertainty stems from the need to predict future conditions under which a given investment will be performed.

This paper presents some of the elements of a comprehensive study on scenario analyzes, whose purpose was to indicate the future conditions of the use of coal in the electricity generation sector in the future (up to 2050) ${ }^{17}$. The modeling studies have used own-developed projections of the future conditions affecting the environment and the fuel and energy system, including:

- The demand for electricity,

- The prices of the available fuels,

- The pace of development of individual energy technologies and related changes in the investment and operating costs,

- The pace of decommissioning depreciated generating capacities of the power system, and hence, commissioning of new generating capacities, needed for covering the expected energy demand.

The direction of development of the EU climate policy, assuming that the current trends will be maintained, which will be reflected by an increase in the obligatory share of renewable energy sources in electricity production and a gradual increase in prices of $\mathrm{CO}_{2}$ emission allowances, has been taken into account (Table 2).

The aim of the optimization model was to minimize the total costs of the system by 2050 , taking into account the assumed level of electricity demand and indicative target on the production of energy from renewable sources. The system costs included capital expenditures on the construction of new generating capacities, fixed and variable costs during the exploitation, and the costs of decommissioning obsolete power plants.

${ }^{15}$ D. Kryzia. Wybór technologii wytwarzania energii elektrycznej w warunkach ryzyka. Studia Rozprawy Monografie nr 195, Kraków 2015, 195 p.

${ }^{16}$ F. Gökgöz, M.E. Atmaca, Financial optimization in the Turkish electricity market: Markowitz's mean-variance approach, "Renewable and Sustainable Energy Reviews" 2012, Vol. 16, No. 1, p. 257-268; S. Awerbuch, S. Yang, Efficient electricity generating portfolios for Europe: maximizing energy security and climate change mitigation, "EIB papers" 2007, Vol. 12, No. 2, p. 8-37.

${ }^{17}$ L. Gawlik (ed.), Wegiel dla polskiej energetyki w perspektywie 2050 roku - analizy scenariuszowe, Katowice 2013, 299 p. 
Table 2. Reference levels of parameters resulting from the implementation of climate policy, assumed in the analyzed scenarios

\begin{tabular}{|c|c|c|}
\hline Year & $\begin{array}{c}\text { Prices of } \mathrm{CO}_{2} \text { emission } \\
\text { allowances, PLN'2011 }\end{array}$ & $\begin{array}{c}\text { Minimal share of electricity } \\
\text { from RES in net final energy } \\
\text { consumption, \% }\end{array}$ \\
\hline 2015 & 41 & 15 \\
\hline 2020 & 62 & 23 \\
\hline 2025 & 66 & 25 \\
\hline 2030 & 70 & 27 \\
\hline 2035 & 74 & 31 \\
\hline 2040 & 78 & 33 \\
\hline 2045 & 82 & 35 \\
\hline 2050 & 87 & \\
\hline
\end{tabular}

Source: L. Gawlik (ed.), Węgiel dla polskiej energetyki...

The target structure of electricity generation in the two scenarios with different assumptions concerning the development of the coal industry in Poland against the fuel structure of electricity generation in the year 2015 is presented in Fig. 3.

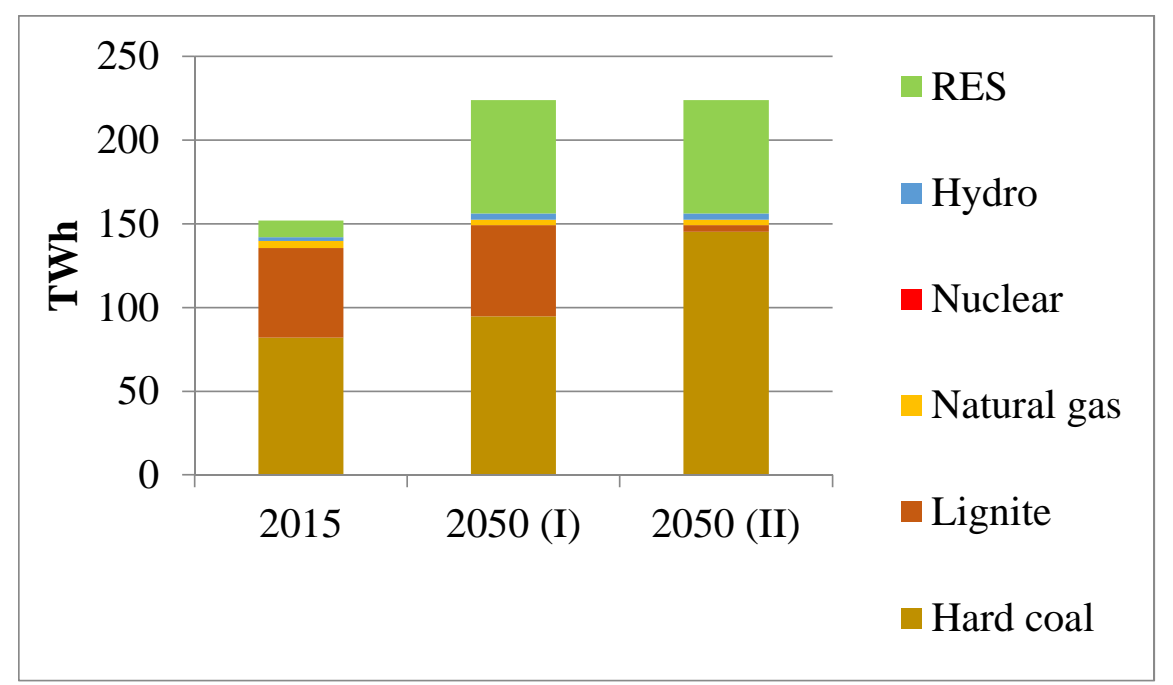

Fig. 3. The fuel structure of electricity generation in the year 2015 and 2050 according to the scenario of the development of the mining industry in Poland (I) and to the scenario of the declining coal mining in Poland (II).

Source: own work based on L. Gawlik (ed.), Węgiel dla polskiej energetyki...

Scenario No. I assumes the continued development of hard coal and lignite mining, taking advantage of the available domestic resources of these fuels. This means that the mining entities will apply for new concessions for conducting mining activities and the opening of new exploitation fields, which will partially replace the depleted resources in abandoned 
parts of mines. In the case of lignite, this scenario implies the possibility of building new opencast mines exploiting new deposits.

The second scenario assumes no exploration of new deposits and a gradual decline of the domestic production as a result of running out of the already available resources.

The size of the production of energy from renewable sources resulted from the assumed mandatory levels. However, other fuel types, including natural gas and nuclear energy, were also available.

In the case of development of the coal industry in Poland (scenario I) technologies based on coal and lignite will be the optimal choices from the point of view of minimizing the system costs. If, however, the mining industry in Poland will not be developing (Scenario II), there will be no new lignite-fired power plants due to the unavailability of this fuel in the country. However, hard coal will continue to be the optimum fuel for power generation. Hard coal is a cheap and easily available fuel in the world market. Therefore, the coal imported to Poland has an advantage over more expensive natural gas and nuclear power. It is also extremely important that Polish power generation sector is currently based on coal while many of the existing power plants were modernized. It should be noted that the currently built coal-fired plants (for example, the Opole power plant) will be a part of Polish power generation system for many years. Relatively low investment costs for the construction of coal-fired power in comparison with investment outlays required for the construction of nuclear units and low fuel costs create an advantage for coal-based investment projects. Meanwhile, natural gas-based investment projects do not show sufficient profitability to be implemented, as the gas prices are too high.

Table 3 shows the volume of electricity production in the year 2050 broken down by fuel type for four scenarios. The prices of natural gas for the year 2050 shown in the Scenario $\mathrm{G}$ are lower by about $20 \%$. Such formation of gas prices in the future will not provide significant advantage of natural gas-based power generation over coal-fired power generation. Assuming the development of mining of hard coal and lignite mining, the structures of electricity production broken down by fuel type for both the Scenario G and Scenario I are very similar.

The Scenario J assumes the development of nuclear power. Such administrative decision is automatically reducing the demand for hard coal, but has very little effect on the use of lignite.

This is very important information for the hard coal mining industry, currently undergoing restructuring process. The target size of the demand for hard coal and hence the target volume of production will depend on whether the government decides to build a nuclear power in Poland.

Table 3. The production of electricity broken down by fuel type, TWh

\begin{tabular}{|l|c|c|c|c|}
\hline & Scenario I & Scenario II & Scenario G & Scenario J \\
\hline Hard coal & 94.6 & 145.2 & 93.8 & 59.0 \\
\hline Lignite & 54.6 & 4.0 & 54.7 & 54.6 \\
\hline Natural gas & 3.2 & 3.2 & 3.9 & 3.4 \\
\hline Nuclear power & 0.0 & 0.0 & 0.0 & 35.5 \\
\hline Hydro & 3.7 & 3.7 & 3.6 & 3.8 \\
\hline RES & 67.9 & 67.9 & 67.9 & 67.9 \\
\hline
\end{tabular}

Source: own work based on L. Gawlik (ed.), Węgiel dla polskiej energetyki... 
The presented scenarios relate to system cost optimization under the assumed conditions. It should be emphasized that the discussed studies assumed the development of CCS (carbon capture and storage) and that this technology will be available for implementation and commercially available from the year 2030 on. However, taking into account the assumed reference levels of parameters resulting from the implementation of climate policy, CCS technology is not an optimal solution. Its implementation is too expensive and requires significantly higher prices of $\mathrm{CO}_{2}$ emission allowances than adopted in the presented scenarios. The main technologies of choice in the presented model are supercritical pulverized coal power plants with net efficiency in the range between 45 and $47 \%$.

Meeting the demand for electricity in the perspective of 2050 year will require new capacities, that is 7.1 to $18.9 \mathrm{MW}$ of hard coal-fired power plants according to Table 3 . In case the domestic mining industry will not be developed and there will be no new lignite mines, the resulting unavailability of this (cheapest) fuel (Scenario II) will be the reason why hard coal - mainly imported - will remain the optimal choice when it comes to minimizing the system costs.

Lower gas prices (the Scenario G) will contribute to a slight increase in the use of this fuel in the energy sector - new gas-fired power plants with a total capacity of $600 \mathrm{MW}$ will replace the existing coal-fired power plants.

For the Scenario $\mathrm{J}$ (nuclear power), that is the construction of three nuclear power units of 1.5 GW each in three subsequent five-year cycles between 2025 and 2035, the optimal solution is to build the same amount of lignite-fired power stations as in other scenarios assuming the development of lignite mining. However, nuclear power plants will reduce hard coal-based power generation. Instead of installing around $12 \mathrm{GW}$ of new capacities based on this fuel (Scenario I and Scenario G), about 7.1 GW of additional capacities will be the optimal solution.

Table 4. New capacities in the power generation system necessary to cover the demand for electricity by 2050 , broken down by fuel type (GW)

\begin{tabular}{|l|c|c|c|c|}
\hline Fuel type & Scenario I & Scenario II & Scenario G & Scenario J \\
\hline Hard coal & 12.0 & 18.8 & 11.9 & 7.1 \\
\hline Lignite & 6.8 & 0.0 & 6.8 & 6.8 \\
\hline Natural gas & 7.3 & 7.3 & 7.9 & 7.7 \\
\hline Nuclear fuel & 0.0 & 0.0 & 0.0 & 4.5 \\
\hline Water & 0.3 & 0.3 & 0.3 & 0.3 \\
\hline Wind power & 21.8 & 21.8 & 21.8 & 21.8 \\
\hline Solar power & 9.6 & 9.6 & 9.6 & 9.6 \\
\hline Biomass & 2.9 & 2.9 & 2.9 & 2.9 \\
\hline Biogas & 1.2 & 1.2 & 1.2 & 1.2 \\
\hline
\end{tabular}

Own work based on Gawlik L. (ed.), Węgiel dla polskiej energetyki...

The use of domestic coal in the energy sector in the future depends on the implemented scenarios. This is shown in Fig. 4.

A characteristic feature is that the demand for coal by the year 2020 is expected to be the same for all scenarios. That means a downward trend to about 40 million Mg. Later on, the demand will depend on the assumed conditions. According to the Scenario G and 
Scenario I, the demand in the year 2050 will amount to around 41 million $\mathrm{Mg}$ of coal per year. In the Scenario J it will be lower (at about 29 million $\mathrm{Mg}$ ). In the case of implementation of the Scenario II, small domestic customers would run out of domestic coal at the beginning of 2030, while from the 2035 on, energy imports would be increasing. In 2050, the entire domestic supply (about 22 million $\mathrm{Mg}$ ) would have been consumed by the energy sector and it would be necessary to import coal (about 37 million $\mathrm{Mg}$ ) to cover the demand of this sector.

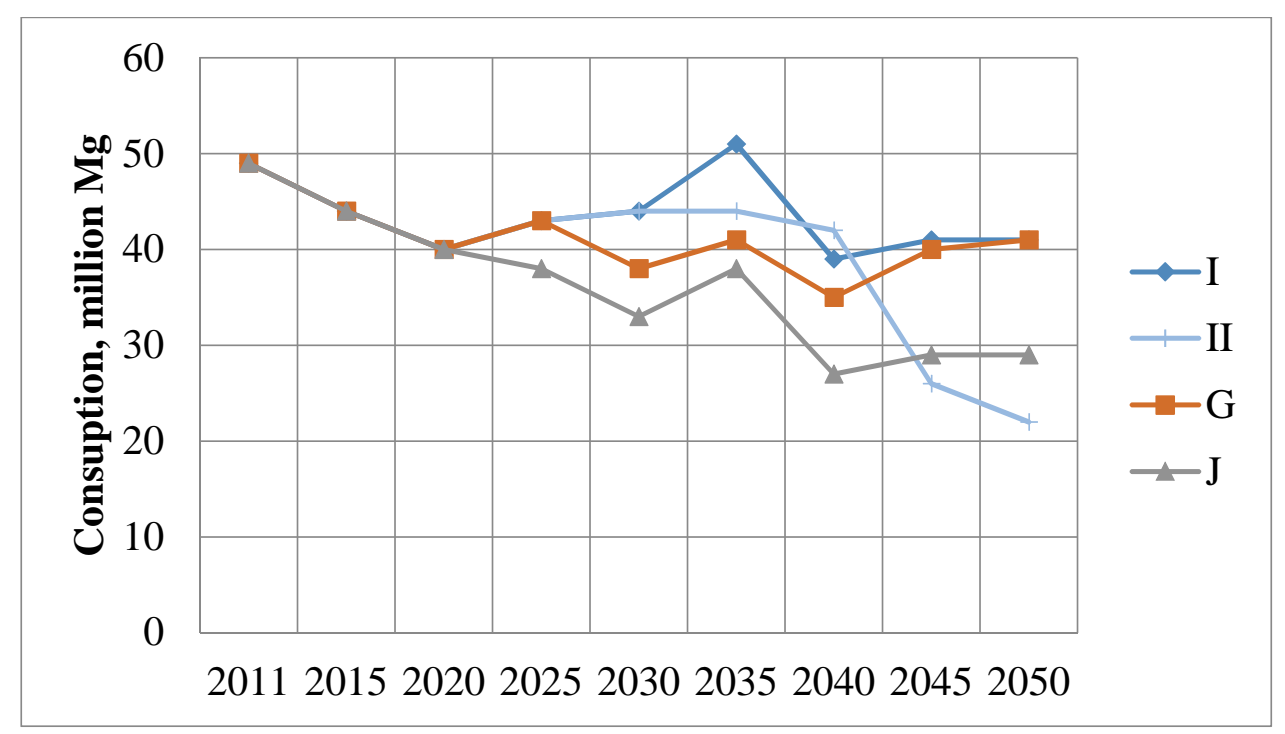

Fig. 4. The consumption of domestic steam coal in power generation in the analyzed scenarios Source: own work based on L. Gawlik (ed.), Wegiel dla polskiej energetyki...

\section{CONCLUSIONS}

The presented scenarios indicate that the current decline in demand for coal energy will continue by the year 2020. This stems from the fact that Poland is obliged to meet the requirements of the European Union regarding the current EU climate policy. In the long run, it is possible to implement different scenarios; however, all of them assume a more or less important role of hard coal in the structure of electricity generation. Their implementation depends on several elements, among which the most important are the government priorities in the field of energy policy.

Assuming the rational involvement of the European Union in the decarbonization of electricity generation, the continued development of hard coal-based power generation is the cheapest way to ensure the availability of electricity in Poland, which will result in moderate increases of prices of $\mathrm{CO}_{2}$ emission allowances.

The decision to build nuclear power in Poland belongs to the government. This solution will result in the diversification of production, however, higher costs will be required. 
The most important conclusion from the performed analysis is that reducing domestic production is important only on a short term. Therefore, restructuring of the hard coal sector must be implemented as soon as possible. The target production volume is dependent not only on the demand for coal but also on the successful development of restructuring process, aimed at long-term economic efficiency of the currently inefficient mines, allowing the domestic coal to compete with imported coal.

Generation of electricity from coal is the cost-optimal solution and therefore the electricity generation based on coal will be developing. In case of a significant reduction in the production, Polish coal will be replaced by imported coal.

The direction of the energy policy of Poland and the legal system favoring the preferred directions depend on the government. It is therefore important to adopt the energy policy of Poland until 2050 as soon as possible. This document will define the target position of coal in the structure of electricity generation.

\section{ACKNOLEDGEMENTS}

This work was done within the framework of statutory research of the Mineral and Energy Economy Research Institute, Polish Academy of Sciences.

\section{REFERENCES}

[1] Agencja Rozwoju Przemysłu S.A. Oddział w Katowicach, data processed on the basis of the results of the survey of public statistics by the Minister of Economy „Coal mining“, executed by ARP SA O / Katowice 2015.

[2] Awerbuch S., Yang S., Efficient electricity generating portfolios for Europe: maximizing energy security and climate change mitigation, "EIB papers“"2007, Vol. 12, No. 2, p. 8-37.

[3] Budzanowski W.M., Target for national carbon intensity of energy by 2050: A case study of Poland's energy system, "Energy" 2012, Vol. 46, p. 575-581.

[4] Communication from the Commission to the European Parliament, the Council, the Economic and Social Committee and the Committee of the Regions. Energy Roadmap 2050, $\operatorname{COM}(2011)$ 885/2 final. European Commission (EC), 2011.

[5] Gawlik L. (ed.), Wegiel dla polskiej energetyki w perspektywie 2050 roku - analizy scenariuszowe. Górnicza Izba Przemysłowo-Handlowa. Wyd. IGSMiE PAN, Katowice 2013, 299 p.

[6] Gawlik L., Szurlej A., Wyrwa A., The impact of the long-term EU target for renewables on the structure of electricity production in Poland, "Energy" 2015, Vol. 92 (Polish Energy Mix), p. 172-178.

[7] Gawlik L., Kaliski M., Kamiński J., Sikora A.P., Szurlej A., Hard coal in the fuel-mix of Poland: the long-term perspective, "Arch. Min. Sci.“ 2016, Vol. 61, No. 2, p. 339-354.

[8] Gökgöz F., Atmaca M.E., Financial optimization in the Turkish electricity market: Markowitz's mean-variance approach, "Renewable and Sustainable Energy Reviews“" 2012, Vol. 16, No. 1, p. 257-268.

[9] Kicki J., Sobczyk E.J., Jarosz J., Stachurski K., Gospodarka zasobami złóż węgla kamiennego $w$ Polsce $w$ latach 1990-2015, Zeszyty Naukowe Instytutu Gospodarki Surowcami Mineralnymi i Energią PAN 2016, No. 92, p. 37-56.

[10] Kryzia D., Wybór technologii wytwarzania energii elektrycznej w warunkach ryzyka. Studia Rozprawy Monografie nr 195, Wyd. IGSMiE PAN, Kraków 2015. 
[11] Kubica K., Szlęk A., Wilk R., Czyste technologie węglowe - badania, rozwój i upowszechnianie wyników, Monografia, Instytut Techniki Cieplnej, Gliwice 2007.

[12] Narodowe Centrum Badań i Rozwoju [online], http://www.ncbr.gov.pl/programystrategiczne/zaawansowane-technologie-pozyskiwania-energii/ available: 20.05.2016.

[13] Polskie Sieci Elektroenergetyczne SA. [online], http://www.pse.pl/index.php?modul= $8 \& \mathrm{y}=2015 \& \mathrm{~m}=12 \&$ id_rap=212 available 1.05.2016.

[14] Rozporządzenie Ministra Środowiska z dnia 24 kwietnia 2012 r. w sprawie szczegółowych wymagań dotyczących projektów zagospodarowania złóż (Dz.U. z 2012 r., poz. 511).

[15] 2015 Trillema Index: benchmarking the sustainability of national energy systems. World Energy Council, London 2015, 151 p. [online], http://www.worldenergy.org/publications/ 2015/2015-energy-trilemma-index-benchmarking-the-sustainability-of-national-energysystems-2/.

[16] European Union, 2015. Energy, transport and environment indicators. Luxemburg Publication Office of the European Union.

\section{WPLYW OGRANICZENIA WYDOBYCIA WĘGLA KAMIENNEGO W POLSCE NA MIX ENERGETYCZNY KRAJU}

Przedmiotem artykułu jest ocena wpływu ograniczenia wydobycia w polskim górnictwie węgla kamiennego na krajowy miks energetyczny. Mając na uwadze obecną sytuację ekonomiczną branży górniczej oraz jej nadrzędną rolę w kształtowaniu gospodarki surowcowej kraju autorzy podjęli próbę analizy wpływu ograniczenia bądź rezygnacji z wydobycia węgla kamiennego z zasobów krajowych na sytuację w sektorze energetycznym w Polsce oraz przedstawili wybrane konsekwencje z tym związane. Istotne jest, że udział tego surowca w krajowym miksie energetycznym z roku na rok maleje, głównie na rzecz gazu ziemnego i odnawialnych źródeł energii. W skali światowej, jak i krajowej obserwowany jest wzrost udziału energetyki wiatrowej w strukturze energetycznej. Rozwój ten jest w głównej mierze skutkiem wprowadzania wymogów dyktowanych prowadzeniem polityki klimatycznej. W głównej mierze wspierane są rozwiązania mające pozytywny wpływ na środowisko i zmiany klimatu. Należy jednak zauważyć, że w 2015 roku ponad 50\% energii elektrycznej pochodziło ze spalania węgla kamiennego w energetyce. Zdecydowana większość polskich elektrowni to elektrownie zasilane właśnie węglem kamiennym. Znacznie mniejszą ilość stanowią elektrownie zasilane innym rodzajem paliwa, w tym również elektrownie zasilane odnawialnymi źródłami energii. Obecnie budowane są również nowe moce wytwórcze oparte na tym paliwie kopalnym, tj. Kozienice, Jaworzno, Opole. Te przesłanki, jak również wyniki szczegółowych analiz wskazują, że węgiel kamienny będzie użytkowany w Polsce jeszcze przez wiele lat.

Słowa kluczowe: wydobycie węgla, produkcja energii elektrycznej, miks energetyczny, prognozy.

DOI: $10.7862 /$ rz.2017.hss.42

Przestano do redakcji: kwiecień 2017 r.

Przyjęto do druku: wrzesień 2017 r. 
